\title{
Unveiling what should remain hidden: ethics and politics of researching marginal people
}

\author{
Michal Ruzicka
}

(C) The Author(s) 2016. This article is available at SpringerLink with Open Access.

\begin{abstract}
The article is a reflection on ethnographic research conducted with poor Roma ("Gypsy”) families under post-socialism, Europe's marginal people par excellence. Living on the periphery of the dominant socio-economic systems, marginal people often exploit precarious resources by means of informal strategies and tactics in an effort to secure their subsistence on a day-to-day basis. The craft of becoming invisible as well as remaining hidden from the gaze of the State apparatus thus might be a key ingredient of living under conditions of limited resources and opportunities. The article is a story of how the author attempted to solve the moral dilemma of what to do with data that are essentially important for understanding social reality, yet at the same time have been meant to remain hidden, never uncovered and never made public to outsiders. The author shows how understanding "the interior" - the subjectivity of marginal people who have severely limited access to resources and social recognition - is never fully possible without understanding the role which "the exterior" plays in shaping its conditions of possibility. The author argues that in order to grasp the subjectivity of marginal people, one first needs to make out the socio-historical conditions that shape the subjectivities of marginal people. Moreover, one needs to recognize the crucial role which the State plays in shaping the larger socio-historical framework that (re)produces their conditions. The moral and ethical dilemma of what to do with research that unveils what should remain hidden thus could be reconceptualized as the primarily political problem of facing the fundamentally unequal relationship between the State and its marginalized subjects and choosing a morally acceptable political position.
\end{abstract}

Keywords Ethics of research · Politics of ethnography · The State · Marginalization $\cdot$ Social exclusion $\cdot$ Resistance $\cdot$ Roma/Gypsies

M. Ruzicka (ه)

Forschungszentrum Menschenrechte, Universität Wien, Hörlgasse 6/9, 1090 Vienna, Austria

E-Mail: michal.ruzicka@univie.ac.at 


\section{Introduction}

As an anthropologist and sociologist who has been conducting ethnographic research among poor Roma families under post-socialism for more than a decade, I have focused on topics such as concrete mechanisms and forms of social exclusion (Ruzicka 2006), the role of kinship in the social organization of secluded Roma communities (Plavjanikova and Ruzicka 2008; Ruzicka 2009), and the role of space and time in the reproduction of Romani marginality (Ruzicka 2011, 2012). Only quite recently did I turn my attention from how the Roma have been excluded "from the outside" to how they perceive, adapt and react to their disadvantaged position in the dominant social and economic system "from the inside".

Refocusing my agenda on the subjective experience and social logic of action under the conditions of social exclusion led me to reconsider the bidirectional relationship between the excluded and the exclusive society (Young 1999). After being acquainted for several years, my informants slowly started to initiate me into the ways they solve the practical problems of overcoming their social exclusion: by utilizing all resources available to them that could be used to make their life easier, regardless of the ethical standards of the dominant society, actively disregarding what the written law says. Moreover, I started to think I now understand how this was one of the ways my informants actively contributed to the negative meanings associated with the Roma/Gypsy ethnicity: "to steal like a Gypsy", "to lie like a Gypsy" (Dictionary 1983, p. 61-62), or "to lie, to deceive, to cheat, to mock" (Dictionary 1989, p. 210). Albeit such a situation could be explained as a case of "symbolic domination" - the dominated actively participating in the system of their domination (Bourdieu [1979] 1984, p. 386; Bourdieu [1997] 2000, p. 198) it would not solve my dilemma: As a social scientist, I was uncertain what exactly to do with data and information that I was aware could easily be used against my informants' interests. I felt that the ethical maxim "do not cause harm to your informants" failed to go along with the necessity to present the findings from my research: An understanding of the logic of action under the conditions of social exclusion and enduring marginality arose from exactly the same information and data that I knew were supposed to remain hidden from the sight of the members of the dominant society.

I was quite surprised not to find a great many social scientists discussing the ethical dilemma I had encountered: what to do in the case that a social scientist discovers information that would explain important social problems, yet at the same time must remain hidden from the gaze of the public. This issue was also an important turning point in my academic career, as I became unable to keep the sharp distinction between my own subjectivity and the object of my research interest. This presented the most decisive crisis in my own research as ethnographer so far, forcing me to re-evaluate my own identity as a scientist, and also to re-evaluate the relationship between my personal and professional career (Wengle 1988).

The process of reorganizing my own research subjectivity has been strongly influenced by Bourdieu's proposal to historicize the object of one's research in order to fully understand how one's social relationship with that object determines the very process of data production and analysis (Bourdieu 1992, p. 218-260), 
together with Deleuze's imperative to study the "relation with the outside" in order to understand the nature of the inside (Deleuze [2002] 2004, p. 255).

This article has several goals. First, the article is meant in part as an intellectual biography of how I reconsidered my object of research (i. e. the phenomenon of enduring Roma marginality). Second, the process is outlined of how I realized that without structural analysis, my phenomenological approach would never deliver a full sociological understanding of this politically (and morally) super-charged topic. With Deleuze, we could say that without discovering how "the outside" shapes "the inside", one would be predetermined to seek explanations of social phenomena in isolation from the determining forces of social history.

This paper is the outcome of an intellectual attempt to make sense of what does not make sense, an attempt to talk about what should not be talked about, and an attempt to unveil what should remain hidden. Refusing to reproduce the image of marginalized Roma as "passive objects" of external circumstances, I came to recognize their agency to rationally adapt to, as well as actively resist, the sociohistorical conditions that reproduce their marginality.

A socio-historical analysis of the conditions from which the subjectivity of marginalized social actors stem led me to reconsider the "moral/ethical dilemma" of unveiling what should remain hidden in terms of taking a strong political stance towards the object of analysis. Conducting ethnographic research with marginalized people is presented here not as a matter of choosing the right methodology, but of choosing the right political perspective - one that allows to unmask the active role of the State in the process of reproducing the marginality of its subjects.

\section{Data, method and the problem of unveiling what should remain hidden}

I have conducted iterative ethnographic research with marginalized Roma (Gypsy) families in the Czech Republic and Slovakia, focusing on topics connected to the issues of poverty, social exclusion and marginalization. Since 2002, my research has been done in several rural "Gypsy settlements" in Slovakia, as well as in several poor neighborhoods in the cities of the Czech Republic, following transnational networks that socially interconnect these two spatially separated areas. Spending altogether more than twelve months in ethnographic fieldwork, I became closely acquainted with several Roma families. I have been re-visiting them (Burawoy 2003) for close to a decade (see c.f. Ruzicka 2011, 2012).

Koloman is a father of five children, trying hard to make his way through life with limited resources available to him and his family. As his Roma parents were unable to take care of him as a child, Koloman was brought up in institutional care until he reached the age of 18 . He was later able to reconnect with his parents' larger family, but as soon as his first son was born out of a partnership with a Roma woman from a different family, they together established a separate household. Having rather difficult relations with his own parents' family, Koloman was accepted to his wife's lineage as a fully fledged member. Popular for being an easy-going man, he also became an important 
source of knowledge and social resources, as he maintained extensive nonkin social ties with his Roma and non-Roma friends from the children's home and the elementary school he attended until $8^{\text {th }}$ grade. Despite never having finished a high school, Koloman was able to keep a steady job under state socialism. As a worker in a state company, Koloman was issued an apartment with a regulated rent in an ethnically de-segregated neighborhood. The family was generally perceived as a large, yet 'trouble-free' Roma family by their neighbors. In the early $1990 \mathrm{~s}$, Koloman got into trouble with the law and spent several years in prison, further enriching the poor of his 'social capital', including both Roma and non-Roma men, many of whom have been associated with the newly forming underground economy. The mid-1990 s was the time when things started to deteriorate: After returning from prison, Koloman was unable to re-enter the labor market and failed to find another steady job in the context of the post-socialist reorganization and privatization of the formerly state-controlled economy. With a lower income - at that time basically limited to their unemployment and other welfare benefits - his family lost eligibility to the comfortable apartment they had been living in and entered the 'free market' of accommodation to experience the full impact of stigma associated with their Roma ethnicity. However disadvantaged economically (low and insecure income) and symbolically (bearing the publically recognized stigma of Roma ethnicity), Koloman became an informal expert in mobilizing and making use of resources available to him on the margins of the dominant socio-economic system, always being able to find a solution to the constantly pressing questions of housing and economic survival.

It was around 2005 when I befriended Koloman and his family. At that time, I was conducting ethnographic fieldwork in one of the "Gypsy settlements" in eastern Slovakia and got to know Koloman's wife's family as those who had left Eastern Slovakia for the Czech Republic during the 1970 s. This led me to expand my fieldwork area from Slovakian Roma settlements to include urban settings in the Czech Republic inhabited by Roma who had departed from their settlements in the $1960 \mathrm{~s}$ and $1970 \mathrm{~s}$ in search for better employment and housing conditions (Davidová 1970). Being a well-known acquaintance to the Slovak branch of the family, Koloman's family accepted me as a trustworthy "gadjo" who kept visiting them every once in a while, asking strange questions in an effort to "study the Romani culture", constantly "reading or writing books". Throughout the years of our mutual friendship, I slowly became an important connection to the world of the gadje, providing help and other services to Koloman's family. From reading and writing official letters to mediating legal and other professional advice, I gradually became a kind of distant "family member" whom they knew they could trust. A somewhat strange but still rather harmless gadjo. In the process of becoming more and more intertwined with Koloman's family, I started to notice a slight but progressive change in how they were treating me: how they talked to me, what kind of information they kept revealed to me etc., as if they knew I would not betray their trust.

A gradual turning point in my research came after I realized that our relationship based on mutual trust became deeper, allowing Koloman to openly discuss with 
me the details of his and his family's social and economic life. From one point, Koloman had no trouble providing me with details about his past (how he got to prison etc.) and present experience, especially with regard to how he managed his family's finances; by that time, he had already lost eligibility to receive State unemployment benefits. I acquired a new perspective on how people like Koloman do things in order to manage their lives on a day-to-day basis, especially by utilizing marginal economic resources available to them either directly on the street or via social networks, mostly in the context of the underground economy. Koloman often openly explained to me how things work on the street, how one has to behave in order to utilize the most viable resources. Along with strategies to make the "right impression" in the eyes of the State - a police officer or a social worker most commonly in this case - I learned about the tactical role which certain strategies (which would be seen by the dominant society as false promises, overt lies, theft, threat or even open violence) played in managing the insecure, rare and constantly fleeting resources in the shadow areas of the underground economy. Koloman never got involved in organized crime, preserving his pride as a lone wolf who is really good in what he does: exploiting economic resources, often at the expense of other actors in the social game. I came to feel that I started to better understand Koloman's own perspective on the world which led me, among other things, to stop perceiving his actions as resulting from his cultural membership, but rather as his own practical strategies and tactics that he himself had learned to utilize in order to be successful in the street economy. Based on my extensive experience with Koloman's family, I realized that there is a certain "core" of informal practices and tactics that not only give a new meaning to what Koloman did on an everyday basis, but that would give me a new understanding of what it is like to live on the margins.

New data and new forms of understanding motivated me to reconsider the complex relationship that existed between my method and data, and between ethical and political considerations. For instance, I was struggling between my ethnographic curiosity ("wow - amazing data!") and my own ethical beliefs ("I just cannot publish this data"). My biggest fear was to unwittingly become an informant to the disciplining State apparatus, providing an informational base that could potentially be used against the interests of my informants. Besides that, I was personally reluctant to being over-involved in the underground economy. I understood that there was a multiplicity of perspectives and ethical considerations that perhaps should be taken into account if I decided to continue my research:

1. Koloman's own moral convictions of what is right and wrong.

2. My own moral convictions of what is right and wrong.

3. The wider society's moral convictions of what is right and wrong, together with hegemonic stereotypes used to justify Roma marginalization.

4. The scientific community demanding research results to be reported, allowing data to be available for peer review.

At first, I did not find the fact that these perspectives exist in mutual conflict to be problematic. Only later did I realize that I have a problem: what to do with the data that at the same time served to "explain" a social phenomenon, yet their nature was that they must remain hidden to the observer, especially to the agents of the 
State. The problem was that, in a sense, I also was the State's agent: a professional scientist paid by the State to provide and publish "data" on what it means to live on the margins as a poor Roma under post-socialism ${ }^{1}$.

Not only my research, but also my data turned political. I knew that the data - if disclosed openly - could serve as a fuel for the anti-Roma discourse by conforming the general stereotype of Gypsies as "smart liars", "cunning pretenders" or "thieves". I became obsessed with imaginary scenarios of how my data could possibly be politically used against those who have trusted me most, my informants. How to say enough without saying too much? The tension between the scientific imperative to "do research and present your results" and the ethical imperative "never cause harm to your informants" was clearly not easily resolved at this point.

As I was thinking my way through the plethora of moral dilemmas and ethical considerations stemming from recent developments in my research, I came to realize that my research was not only about the relationship between my informants and myself. Rather, other powerful actors were to be included into how I perceived the issue: the dominant society (with its pre-constructed notions and stereotypes about the Roma) as well as the State with its primary agenda to preserve the social and political status quo by means of disciplining those who are perceived as a threat to the symbolic order of the dominant society (Sibley 1995). This consideration eventually led me to integrate the relationship between the marginal (marginalized Roma in my case) and the central (the State and its institutions) into my research on conditions that make the enduring Roma marginality possible.

\section{The relationship between the State and marginal people}

My argument here is that in order to understand the perspective of marginal people, one first needs to understand how such a perspective has been shaped by sociohistorical processes and structures. The more limited access is to resources and capital, the more is one dependent on, and constrained by, conditions that form the external context of one's life. In order to make sense of various internal strategies and tactics used by marginal people to overcome obstacles in their ordinary lives, we first need to consider how the external socio-historical context produced such obstacles.

Marginal people always enter the scene a posteriori, in the sense that they must adapt to the system of institutions and regulations that has preceded them. This does not mean that marginal people are completely powerless, reduced to passive objects without any possibility to actively respond to and/or transform their predicament. Even the most impoverished people aspire to give meaning to their lives and to manage the resources available to them in their struggle for social recognition.

\footnotetext{
1 This article was supported by the national Czech Science Foundation (project no. P404/12/P024).
} 


\subsection{The State against the Gypsies: casting out the outcasts}

There are not many sources that could help us understand the historical roots of Roma marginality in Europe. However, historians more or less agree that the Roma occupied low and marginal areas of social space since they emerged in Europe around the 14th century (Crowe 2007; Horváthová 1964). In other words, "in preindustrial Europe ... the Gypsies were harried as they travelled and harassed when they settled" (Stewart 1997, p. 4). From historical sources, we can assume that antiGypsy sentiments had been permeating public opinion as early as in the 16th century, and that they were only boosted by the social and economic insecurities generated by the Thirty Years' War in the 17th century (Crowe 2007, p. 35). From that century onwards, the Gypsies became an object of state control through banishment, expulsion or physical extermination (see esp. Horváthová 1964, p. 60-61, or Kappen 1963). Under the rule of the Habsburgs (esp. Maria Theresa and her son Joseph II.) a slight change in the State policy occurred: From then on, the Roma were not to be persecuted due to the sole fact of their ethnicity, but instead be settled, renamed and forbidden to speak their own language in order to be fully assimilated and turned into working and tax-paying "New Citizens" (Barany 2002, p. 93). Failing to fulfill its goals, the policy of total social and economic assimilation of the Roma population was later abandoned - once again - in favor of exclusionary rather than "integration" or assimilation policies, again orchestrated by the State. The exclusionary tendency of the State towards the Roma in Europe undoubtedly reached its culmination in the Roma holocaust during the Second World War (Lewy 2000).

In his seminal work, Die Krisis der europäischen Wissenschaften und die transzendentale Phänomenologie, Husserl made a comment on Gypsies as an element which, in his mind, did not belong to Europe. Of course, Husserl was not personally responsible for the historical persecution of the Roma in Europe, yet he openly revealed what I think has been the dominant way of conceptualizing the Gypsies: as a fundamentally alien element that does not fit into the idea of how society and the State is, or should be, organized and/or understood (Husserl 1970, p. 273):

We pose the question: How is the spiritual shape of Europe to be characterized? Thus we refer to Europe not as it is understood geographically, as on map, as if thereby the group of people who live together in this territory would define European humanity. In the spiritual sense the English Dominions, the United States etc., clearly belong to Europe, whereas the Eskimos or Indians presented as curiosities at fairs, or the Gypsies, who constantly wander about Europe, do not.

Together with the era of Habsburg rule, state socialism in East-Central Europe represents the most complex attempt to integrate the "citizens of Gypsy origin" into the mainstream society by means of total social and economic assimilation. The Roma population was supposed to be integrated, and the "Gypsy question" thus be solved, by means of specific economic (mandatory labor), cultural (mandatory education) and social (spatial and ethnic desegregation) policies. There is too little space to go into details, but in retrospect, the "integration" policies under state 
socialism failed generally as they were unable to solve the problem of enduring Roma marginality (Barany 2002; Guy 1975; Kalvoda 1991; Pavelčíková 2004).

To conclude the brief historical excursus into the history of Roma marginality in East-Central Europe: Historical records show that the Roma were never allowed to become fully fledged members of the dominant social and economic systems, constantly being perceived as "unwanted elements" and targeted by either exclusionary, or assimilationist policies - always orchestrated and directly facilitated by the State and its disciplinary apparatuses. Such a historical perspective would reveal the fundamental role which the State has always played in shaping the external context for the "pariah group par excellence" (Kornblum 1975, p. 124).

As to the contemporary state of affairs, the European societies have obviously made little progress in solving the problem of enduring Roma marginality. My argument is that the State (including state-like organizations such as the European Union) still plays a crucial role in molding the life context of the Roma (Gypsies) in an attempt to control and contain them. At this point, I would argue that since the fall of state socialism, the State ${ }^{2}-$ again, alongside state-like actors such as the European Union - has been producing an inconsistent conglomeration of policies and practices that often take the form of inclusive rhetoric and policies from above, supplemented by exclusionary practices from below. One of the European Union's largest integration projects entitled "Decade of Roma Inclusion 2005-2015" declared its goals as follows ${ }^{3}$ :

The Decade of Roma Inclusion 2005-2015 is an unprecedented political commitment by European governments to eliminate discrimination against Roma and close the unacceptable gaps between Roma and the rest of society. The Decade focuses on the priority areas of education, employment, health, and housing, and commits governments to take into account the other core issues of poverty, discrimination, and gender mainstreaming.

However well intended the project to end the centuries of Roma marginality has been, it seems that we are still quite far from fulfilling the Decade's goals. Apart from yielding some unquestionably positive results, the years 2005 to 2013 have witnessed a new wave of anti-Roma sentiments, violence, and anti-Roma policies and practices throughout Europe. The massive expulsions and deportations of Balkan Roma/Gypsies from the countries of Western Europe ${ }^{4}$, the recent killings of Roma in Hungary ${ }^{5}$, society's broad anti-Roma protests 6 , and building fences and walls

\footnotetext{
2 In this article, I understand State as "bureaucratic field": a relatively independent conglomerate of institutions responsible for running the State and for imposing its own vision of reality upon social agents under its rule (Bourdieu 1994).

3 http://www.romadecade.org/about-the-decade-decade-in-brief.

4 http://www.bbc.co.uk/news/world-europe-11020429, http://en.wikipedia.org/wiki/French_Roma_ expulsion, .http://www.amnesty.eu/en/news/press-releases/all/france-record-number-of-evictions-ofroma-0659/\#.UnTMPfKjLdU.

5 http://www.bbc.co.uk/news/world-europe-23586440.

6 http://www.romea.cz/en/news/czech/czech-republic-anti-roma-demonstrations-tomorrow-in-duchcovover-assault.
} 
around Roma neighborhoods in the Czech Republic, Slovakia and Romania ${ }^{7}$ only reveal that the well intended inclusive rhetoric at the European Union level is not always accepted as a point of departure for concrete practices and policies at the local (municipal) level. In the meantime, international monitoring bodies continue to publish reports showing how the inequality and discrimination of Eastern European Roma has barely been reduced (Dzeno 2006; Halász 2007; Amnesty 2009; FRA 2009; GAC 2006; Halász 2007; Ringold 2000).

The plethora of contemporary anti-Gypsy sentiments, practices and policies, both in the past and present, forces one to rethink the role of the State in the reproduction of enduring Roma marginality. From a historical perspective, the State should not be seen as a neutral body of bureaucratic institutions, but rather as an active agent who shapes the ways in which its marginal people are able to live their lives. It is the State which is responsible for establishing and maintaining the external context within which the marginal people are forced to find their own ways how to live lives worth living. We can illustrate the fundamental role which the State plays in controlling and disciplining its Roma population with a concrete example - it will allow us to see how anti-Roma policies are openly enforced today at the local (municipal) level from below, clearly in conflict with the European Union's integration rhetoric imposed from above.

A new wave of "conservatism" swept through Europe-in-crisis, creating an open space to be filled with another new wave of anti-Roma practices and policies. The spatial (residential) segregation of Roma in Eastern Europe is a case which illustrates how symbolic purification of public space from dangerous and defiling elements (Sibley 1995) has become one of the tools for excluding those who have been perceived as outsiders. "Anti-homeless architecture" and anti-loitering law do not only "purify" public space from unwanted elements (such as the homeless, vagrants, Gypsies and other threatening and symbolically defiling agents) - it transforms the very idea of public space, while forcing citizens to withdraw from it to take refuge in their private spheres. To give an example of these practices, the following passage is taken from a 2011 public notice posted in the city of Rotava in the western parts of Bohemia:

The subject of this [public notice] is the ban on sitting, staying, walking on or leaning against build structures that are owned by the municipality ... It is forbidden to place obstacles in the public places (benches, desks, chairs and other furniture used to sit on, tables, grills, blankets and similar textiles) without the explicit consent of the municipality, because these are activities that could disturb the public order in the city or could be in conflict with good conduct, public safety, health and property. ${ }^{8}$

The city of Rotava, where I have carried out parts of my fieldwork, witnessed an inflow of Roma migrants from other regions of the Czech Republic in the past decade, arousing strong anti-Roma sentiments and actions on the part of local society

\footnotetext{
7 http://en.wikipedia.org/wiki/Roma_wall, .http://www.bbc.co.uk/news/world-europe-23767036.

8 The public notice is available on-line at: http://www.rotava.cz/e_download.php?file=data/editor/187cs_ 8.pdf\&original=OZV_4_2011.pdf.
} 
and local state structures. Public notices such as the one above, along with concrete practices (such as the removal of benches from public space), have been observed in other cities and towns in the Czech Republic and may be interpreted as a form of social control exercised against those who are perceived as posing a threat to the established social and symbolic order (Bancroft 2005; Sibley 1995).

After assessing the fundamental role which the State (bureaucratic field) plays in producing specific material and socio-legal context within which the Roma need to find their place, we now address this process in detail.

\subsection{Gypsies against the State: living on the edge as an act ofaptation and resistance}

Marginal people navigate their everyday lives on the fringes of the dominant socioeconomic system, often having to deal with the stigma attached to their social (and/or ethnic) status. Being deprived of full access to resources which are otherwise accessible to members of the society at large, lacking skills and knowledge to be perceived by the distributors of social recognition, as well as having limited access to social services, marginal people have to rely on irregular, precarious and often unpredictable sources of income.

The economic strategies of marginal people can be seen as "open" in the sense that these people must be ready to make use of such opportunities and resources (both material, social and informational) as soon as they emerge (Day et al. 1999). Life on the margins consists mainly of waiting and waiting again for the right opportunity.

Koloman's life may appear to the outside observer as slow, if not 'boring' (it is he himself who describes his life as boring). In fact, 'not much has happened, you know' is the most common answer I received at any time when asking what has changed since our last encounter. Such a statement reflects the nature of things most of the time: 'nothing has happened' in the sense that no big changes have occurred in Koloman's family's life. Often, however, I was quite surprised to find rather dramatic changes taking place rather suddenly: Koloman finding a new apartment to rent for his family, or his unexpectedly leaving the city for an expedient job that 'you know, just suddenly appeared' ... To put it in another words: in his life, Koloman usually waits. Unhappy with his and his family's current living situation, Koloman waits for an opportunity: an opportunity that is unpredictable, since it often pops up suddenly, unannounced and unanticipated. In this sense, Koloman relies not on the limited amount of recognized forms of capital (money, education or skills utilizable in the labor market), but rather on resources embedded in social capital that he is not aware of yet: a friend offering a part-time job at a construction site, an acquaintance suggesting a risky but relatively profitable 'deal', or another random resource which could be utilized to make Koloman's family's life more bearable.

Koloman's case corroborates the observation that life on the margins operates by means of "isolated actions, blow by blow ...," leading marginal people to "vigilantly 
make use of the cracks that particular conjunctions open in the surveillance of the proprietary powers" (de Certeau 1984, p. 37). After I turned my attention to how Koloman manages the unpredictable resources and opportunities, I realized the importance of "impression management" for his relative success not only in the underground economy. I have no objective way to assess Koloman's craft to induce the right impression in the right people, yet this skill has astonished me so many times: making a great impression in the eyes of the landowner, his children's schoolteacher, the social worker responsible for assessing the needs of his motherin-law, the judge in his eldest son's court case ... and the list could go on.

Not only Koloman, but also other Roma families living on the margins whom I have come to know, often unemployed and thus depending on irregular and unpredictable sources of income, are forced to rely on irregular sources of income: from actively searching for materials to be collected, recycled (and/or repaired) and then sold, to exchanging services for cash (mostly by providing cheap unskilled labor, or more informal services), to passively waiting for the "right moment" to utilize their personal skills to effectively act and then disappear without being noticed. The craft of impression management and the art of becoming "invisible" come hand in hand. These forms of economic strategies remain relatively under-researched, perhaps due to the fact that they have been morally condemned by both the dominant society and the State apparatus (along with those researchers who, fearing that their research could contribute to their informants' bad reputation, simply "ignore" such practices). This includes such arts and crafts as "impression management" in the presence of utilizable resources, beggary, or even thievery (Horváthová 1964, p. 330; Sutherland 1975, p. 28).

Having their lives relatively determined by their disadvantaged position with regard to social and economic resources embedded within the dominant social and economic system, marginal people are nevertheless still a part of it and are never completely "excluded". Stigmatized by both their ethnicity and economic strategies, these people never find themselves completely "outside" the socio-economic system. Living on the margins of a system means not to live outside of it, but on its fringes in the shadow area where formal social control is relatively weaker. Limited access to the recognized forms of capital does not rule out having access to irregular and "morally questionable" resources (i. e. those which are "morally questionable" from the perspective of the members of the dominant society).

The relational perspective on the State and its marginals (i.e. the mutual relationship between the center and its periphery) allows us to recognize that marginal people are never totally "excluded"; their life is possible only by means of utilizing marginal and often stigmatized (but never fully "excluded") resources. In other words, marginal people can be fully understood only once we recognize how they are actually embedded within the dominant system, albeit marginally. That is exactly why the Roma "cannot be understood in isolation from the wider society of which they have always formed a part" (Bloch 1997, p. xiv). People without a fixed and secure position in society, such as the Roma, "maintain their autonomy by adapting to the dominant culture" in the sense that they "have successfully stayed apart from the larger society because that society provides their economic base" (Sibley 1981, p. 14; see also Sway 1984). In other words, there is a "paradox of Gypsy 
ethnicity" to be explained: "how Gypsies keep themselves distinct while appearing to assimilate" (Silverman 1988, p. 273; see also Okely [1983] 1992).

Marginal people who are economically dependent on the dominant society which at the same time excludes them must make sure to give the "right impression" in the eyes of the beholder. Koloman is very keen on how he and his actions appear to the people "who have power" (by "people in power", he means State agents such as policemen, social workers and other state bureaucrats, teachers, landlords, doctors and - perhaps - also ethnographers). Koloman recognizes that his family depends to a certain degree on the impression they produce in these agents. People who are almost constantly subjected to the controlling and disciplining gaze of the State are simply forced to develop methods of "impression management" (Gmelch 1986, p. 313-314; Silverman 1982; for an analytic frame of studying strategies of impression management, see Goffman 1969), enabling themselves always to wear the proper "mask" when on "stage" (Goffman 1959). People selling "street newspapers" develop techniques to make themselves more visible without "annoying" the by-walkers too much, so do beggars who have mastered techniques to arouse compassion in bystanders. Koloman also has particular strategies and techniques that "work" in the sense that they deliver positive results: making the right impression and thus actualizing potential resources.

Making the right impression, or having the process of impression management under control, is a solution to the problem of how to appear in the eyes of the (always possibly exclusionary) beholder. Another solution would be to "become invisible", i. e. to produce a discontinuity between appearance on the outside, and autonomy and sense of identity on the inside. Because of their marginal status, "the Rom have developed one set of rules for behaviour in obtaining economic and political gain from the gaje and another set of rules for the same behaviour with their own people" (Sutherland 1975, p. 20). Both the gadje and the State (especially when they meet in the figure of the policeman, the teacher, the social worker, the journalist or the landlord) are always potentially threatening forces. In minatorial situations, and in those in which "impression management" is out of the question, marginal people can resort to "becoming invisible" as an ultimate means of deflecting the gaze of the State's disciplinary agents. With regard to "becoming invisible" as the everyday strategy of marginalized people, a particular case might help to illustrate the main point here.

Academic interest has for some time focused on researching Roma migrations, especially those from the East to the countries of Western Europe (Guy 2003; Lee 2000; Matras 2000; Guy et al. 2004). Recent Roma migration has generally been perceived and researched as "a way of solving the economic problems" (Uherek 2004, p. 91), or as a means of escaping socio-economic and political problems, such as discrimination, or as an escape from serious interpersonal conflict (Weinerová 2004, p. 114). Vašečka and Vašečka (2003) mainly regard modern Roma migration as a result of disillusionment and the degradation of the socio-economic status of the "Romani socialist-style middle class" (Vašečka and Vašečka 2003, p. 37), which are again basically economic motives. Prónai in his article on Gypsy migration in Hungary (2004) states that the motivation for migration among the Hungarian Gypsies has been economic, but often with some political considerations as well 
(Prónai 2004, p. 126). Matras' conclusions on the overall motives and causes of recent Roma migrations are in accord with those of the above-mentioned authors, as he sees such migrations to be motivated by reasons of economic or personal security (Matras 2000, p. 37-38). Without questioning the importance or validity of such claims, my own ethnographic experience led me to a slightly different conclusion regarding the possible causes of contemporary flows of Roma migration (see Ruzicka 2009).

I refused to "fit" my research experience and my data into the pre-established categories of economically and politically motivated migration, as I realized that it is perhaps impossible to generalize Roma migrations under one analytical umbrella (Grill 2011, p. 81). To avoid the pitfall of pre-established categories, I proposed another category: that of "invisible migration." Current research, I argue, has focused mostly on the "visible" forms of Roma migrations - receiving the highest level of media coverage, they become visible on account of the strongest social and political interest (Clark and Campbell 2000). Not only does such a perspective conform to the image of the overall Gypsy history as a history of "forced migration" - a history of "exodus" (Kendrick 2004; Clébert 1967, p. 46). It also presents Roma migration as being caused by some exogenous forces. In my own ethnographic research, I observed forms of migration that did not fit into the category of labor or political migration, nor was I able to see any exogenous forces that would limit the choices of my informants. Due to the particular political development in former Czechoslovakia, and due to the State's policy of "liquidation of Gypsy settlements" in the 1960 s and 1970 s, parts of Roma families from the Gypsy settlements in Eastern Slovakia moved to Czech industrial cities to seek better housing and employment opportunities (Jurová 1996). Other parts of these families sometimes refused to be moved, remaining in their settlements. Kin-based social networks, now stretching between the Czech and Slovak states, have often been maintained for decades and presently serve as a kin infrastructure facilitating forms of Roma migration. Applied to migration such kin-based networks have also been used for such "endogenous" reasons as gathering and maintaining resources or identifying suitable spouses (for details, see Ruzicka 2009). Due to the fact that these forms of Roma migration have been going unnoticed by the dominant society (i.e. not arousing anti-Gypsy sentiments, nor stimulating any form of media coverage, not to speak of academic research), I referred to them in terms of "invisible migration." A further interpretation might be that such "invisibility" has been a conscious strategy of the marginalized people who at once need to gather resources available through their kin networks, while remaining hidden from the gaze of the outsider (Williams 1982). There are forms of migration that go unnoticed by the State and by "outsiders", i. e. by members of the dominant society (bureaucrats, policemen, ethnographers etc.) who are always seen as possessing the power to endanger one's security or chances for success.

Marginal people navigate their everyday lives with limited resources, constantly being scrutinized and subjected to the omnipresent gaze of the state institutions and members of the dominant societies. Being subjected to various forms of formal and informal social control, these people must maintain the right impression by subjecting themselves to the formal and informal demands, while at the same time 
keeping distance from them in order to preserve their own identity, sense of selfworth, and cultural autonomy. A certain compromise between submission to those in power and keeping distance from them is thus a crucial determinant of the craft of living on the margins.

Marginal people apply contextual tactics rather than explicitly and deliberately planned strategies to navigate their lives through the space of limited resources, constantly being observed by agents of social control. In other words, these tactics are used to "maneuver 'within the enemy's field of vision' ... and within enemy territory" (de Certeau 1984, p. 36-37). The art of "correct" impression management, along with the craft of going unnoticed, invisible, and remaining hidden, is one of the most important forms of the "art of the weak" (de Certeau 1984, p. 37). The problem arises when these smart tactics, these "weapons of the weak" (Scott 1985), seen as the last resort in their own terms, suddenly become transparent, visible and unveiled, exposed to the panoptical eye of the State and its' servants.

\section{Discussion and conclusion}

Conducting research with marginalized people implies an investigation into the complex, yet rather unequal relationship between those people and the State. The State has for centuries been responsible for shaping the historical and institutional context within which the marginalized Roma have been forced to (re)organize their lives and everyday experiences. As a center of power serving the needs of the ruling élite, the State has also been concerned with disciplining those agents who "do not fit" into its dominant version of reality (Foucault 1977). European Roma, as we have seen in section 3.1, have for example been the target of exclusionary and/or assimilation policies for the most of their presence on European territory. Not complying with the symbolic image of how "proper citizens" should organize their social and economic affairs, the Roma have been forced to occupy marginal spaces on the fringes of the dominant social and economic systems. Literally obliged to accept their structurally marginal position, the marginalized Roma established a specific craft of living under the conditions of resource scarcity. Not accepting the rules of the dominant, the Roma refused to be assimilated into the sedentarized societies under the rule of the State, remaining relatively free from its rule and finding their identity as those who struggle "against the State" (Clastres [1974] 1989, p. 218), as people who do not want to be integrated (Clastres [1980] 2010; Gmelch 1986; Scott 2009). Giving up their economic autonomy for cultural autonomy (understood here as not being assimilated into the dominant system under the rule of the State) and refusing to become fully integrated, the Roma literally sentenced themselves to living on the margins as despised "internal outsiders" (Bancroft 2005, p. 18).

To make their lives more bearable, to maintain a sense of autonomy and selfworth, those who live on the margins often develop a set of practical tactics which allow them to keep distance from the dominant society while utilizing its resources. The problem of structure vs. agency, represented as adaptation vs. resistance in the case of the Roma, can thus be reviewed in a new light. Resistance is adaptation. The State, with its exclusionary policies and practices, creates a specific context 
to which the subjects on its territory must adapt, mainly by means of generating efficient survival strategies and practical tactics to overcome their disadvantaged position with regard to resources otherwise commonly available to the fully fledged members of the society. In this sense, the State can be seen as a structuring principle which has the power to shape the habitus of its subjects; subjects occupying marginal areas will therefore have a tendency to develop habitus attuned to living on the margins.

Now I understand the uneasiness which I felt when Koloman started revealing to me the particular strategies and tactics which he had been using to maximize the "profits" from living on the margins. The uneasiness, manifesting itself in the form of "moral dilemmas" outlined at the beginning of this article, was in fact a function of the distance between Koloman's habitus and my own habitus - the habitus of a white middle-class university-educated male who is predestined to be relatively successful in the world orchestrated and organized by the State; I was thinking like a State (Scott 1998), taking the State's perspective as my own moral perspective.

Now I understand that the "moral dilemmas" I experienced during my fieldwork actually were a manifestation of the distance between my own and Koloman's class positions (understood here as mutually relative positions in social space) (Bourdieu [1993] 1999). It was only after I integrated into my phenomenological (ethnographic) approach (see section 2) a structural and historical analysis of the relationship between the marginal and the central - the State - (see section 3) that I was able to "resolve" the moral dilemmas I had previously encountered.

In my research, I have studied some practical strategies and tactics that enable marginal people to materially survive and still maintain their cultural autonomy by keeping a distance to the agents of the State. Such strategies and practices, often perceived as "illegal", "morally wrong", or at least "morally ambiguous" from the perspective of the dominant, nevertheless work in the sense that they provide solutions to practical problems associated with living on the fringes of the dominant system. The toolkit of hidden strategies and tactics, at once passive adaptation and active resistance, is an important ingredient of living on the margins. As such, these must never be revealed to the outsider, as "invisibility" - at least in this case - is the very condition of its possibility.

Research in marginality, social suffering and social exclusion inevitably involves research into the fundamentally unequal relationship between the center and the periphery, between the State and marginal people who live on its margins. Since all forms of inequality are arbitrary in essence, based on social history and habit rather than on reason (Bourdieu [1997] 2000, p. 94-95), research in social inequality is always necessarily a political undertaking. The social scientist must then reject the idea of remaining "politically neutral", simply because the social analysis of marginality and inequality is inevitably a political task. Social scientists are thus required "to choose which side they are on" (Bourdieu [1997] 2000, p. 83-84). How else to distinguish publishable "data" from data which should remain hidden?

An epistemological perspective that carefully objectifies (Bourdieu [1980] 1990, p. 25) the complex relation between unequal actors (marginal people and the State in our case) has a potential to produce a relational model of social reality without blaming the victim and without taking sides based on personal sympathy while being 
able to unmask the central role the State plays in the system of social reproduction (Wacquant 2010). Science does not only have tools to unveil what should remain hidden, but also has tools to unveil what should become visible: the ways in which the State produces and reproduces the marginality of its subjects by shaping the conditions which make their lives possible.

Acknowledgements I would like to thank Andrea Fritsche with whom I held long discussions related to the topic of this paper and who supported me by reading its first draft. This article was possible only by the support of the Czech Science Foundation (project no. P404/12/P024 "Responses to Exclusion: Poor Roma Families under Post-Socialism").

Open access funding provided by University of Vienna.

Open Access This article is distributed under the terms of the Creative Commons Attribution 4.0 International License (http://creativecommons.org/licenses/by/4.0/), which permits unrestricted use, distribution, and reproduction in any medium, provided you give appropriate credit to the original author(s) and the source, provide a link to the Creative Commons license, and indicate if changes were made.

\section{References}

Amnesty. 2009. Amnesty international report 2009, Czech Republic. http://thereport.amnesty.org/en/ regions/europe-central-asia/czech-republic.

Bancroft, Angus. 2005. Roma and gypsy-travellers in Europe: modernity, race, space and exclusion. Burlington: Ashgate.

Barany, Zoltan. 2002. The East European gypsies: regime change, marginality, and ethnopolitics. Cambridge: University of Cambridge Press.

Bloch, Maurice. 1997. Foreword. In The time of the gypsies, ed. Michael Stewart, xiii-xv. Oxford: Westview Press.

Bourdieu, Pierre. 1984. Distinction: a social critique of the judgement of taste. Cambridge: Harvard University Press. Erstausgabe 1979.

Bourdieu, Pierre. 1990. The logic of practice. Stanford: Stanford University Press. Erstausgabe 1980.

Bourdieu, Pierre. 1992. The practice of reflexive sociology. In An invitation to reflexive sociology, eds. Pierre Bourdieu, and Loï Wacquant, 218-260. Chicago: University of Chicago Press.

Bourdieu, Pierre. 1994. Rethinking the state: genesis and structure of the bureaucratic field. Sociological Theory 12(1):1-18.

Bourdieu, Pierre. 1999. Understanding. In The weight of the world: social suffering in contemporary society, ed. Pierre Bourdieu, 607-626. Stanford: Stanford University Press. Erstausgabe 1993.

Bourdieu, Pierre. 2000. Pascalian Meditations. Stanford: Stanford University Press.

Burawoy, Michael. 2003. Revisits: an outline of a theory of reflexive ethnography. American Sociological Review 65:645-679.

de Certeau, Michel. 1984. The practice of everyday life. Berkeley: University of California Press.

Clark, Colin, and Elaine Campbell. 2000. Gypsy Invasion': a critical analysis of newspaper reaction to Czech and Slovak Romani asylum-seekers in Britain, 1997. Romani Studies 1(10):23-27.

Clastres, Pierre. 1989. Society against the state: essays in political anthropology. New York: Zone Books. Erstausgabe 1974.

Clastres, Pierre. 2010. Archeology of violence. Los Angeles: Semiotext(e).

Clébert, Jean-Paul. 1967. The Gypsies. Harmondsworth: Penguin books.

Crowe, David. 2007. A History of the Gypsies of Eastern Europe and Russia, 2nd edn., New York: Palgrave Macmillan.

Davidová, Eva. 1970. The gypsies in Czechoslovakia, part II. Journal of the Gypsy Lore Society 50(1-2):40-54.

Day, Sophie, Evthymios Papataxiarchis, and Michael Stawart. 1999. Lilies in the field: marginal people who live for the moment. Boulder: Westview Press.

Deleuze, Gilles. 2004. Nomadic thought. In Desert Island and other texts, 1953-1974, ed. Gilles Deleuze, 252-261. Los Angeles: Semiotext(e). 
Dictionary. 1983. Slovník české frazeologie a idiomatiky [Dictionary of Czech Phraseology and Idiomatic]. Praha: Academia.

Dictionary. 1989. Slovník spisovného jazyka českého I. A-G [Dictionary of Czech standard language, vol. 1, A-G]. Praha: Academia.

Dzeno. 2006. Forced out: the problem of Roma evictions in Europe. http://www.romadecade.org/4983.

Foucault, Michel. 1977. Discipline and punish: the birth of the prison. New York: Pantheon Books.

FRA. 2009. Housing discrimination against Roma in selected EU Member States: An analysis of EUMIDIS data.http://fra.europa.eu/fraWebsite/attachments/Roma-Housing-Analysis-EU-MIDIS_en. pdf.

GAC. 2006. Analysis of socially excluded Roma localities in the Czech Republic and absorption capacity of entities involved in this field. Prague: Gabal Analysis \& Consulting.

Gmelch, Sharon. 1986. Groups that don't want in: gypsies and other artisan, trader, and entertrainer minorities. Annual Review of Anthropology 15:307-330.

Goffman, Erving. 1959. The presentation of self in everyday life. New York: Doubleday Anchor Books.

Goffman, Erving. 1969. Strategic interaction. Philadelphia: University of Pennsylvania Press.

Grill, Jan. 2011. From street busking in Switzerland to meat factories in the UK: a comparative study of two Roma migration networks from Slovakia. In Global connections and emerging inequalities in Europe: perspectives on poverty and transnational migration, eds. Deema Kaneff, and Frances Pine, 79-102. London: Anthem Press.

Guy, Will. 1975. Ways of looking at Roms: the case of Czechoslovakia. In Gypsies, tinkers and other travellers, ed. Farnham Rehrfisch, 201-226. San Francisco: Academic Press.

Guy, Will. 2003. 'No soft touch': Romani migration to the U.K. at the turn of the twenty-first century. Nationalities Papers 1(31):63-79.

Guy, Will, Zdenek Uherek, and Renata Weinerova (eds.). 2004. Roma migration in Europe: case studies. Münster: LIT.

Halász, Katalin. 2007. The situation of Roma in Europe. ENAR shadow report 2007. http://www. romadecade.org/files/downloads/General\%20Resources/The\%20situation\%20of\%20Roma\%20in $\% 20$ Europe $\% 202007$.pdf.

Horváthová, Emilia. 1964. Cigáni na Slovensku: Historicko-etnografický náčrt [Gypsies in Slovakia: a historical and ethnographical study]. Bratislava: Vydavatelstvo slovenskej akademie vied.

Husserl, Edmund. 1970. The crisis of European sciences and transcendental phenomenology. Evanston: Northwestern University Press. Erstausgabe 1937.

Jurová, Anna. 1996. Rómska problematika 1945-1967: dokumenty, 3. Čast' (Roma issues 1945-1967: Documents, part III.). Praha: Ústav pro soudobé dějiny.

Kalvoda, Josef. 1991. The gypsies of Czechoslovakia. In The gypsies of Eastern Europe, eds. David Crowe, and John Kolsti, 93-115. New York: M.E.Sharpe.

Kappen, O. 1963. A Prague edict against gypsies (1710). Journal of the Gypsy Lore Society 42(3-4):119125.

Kendrick, Donald. 2004. Gypsies: from the ganges to the thames. Hatfield: University of Hertfordshire Press.

Kornblum, William. 1975. Boyash gypsies: shantytown ethnicity. In Gypsies, tinkers and other travellers, ed. Farnham Rehfish, 123-138. London: Academic Press.

Lee, Ronald. 2000. Post-communism Romani migration to Canada. Cambridge Review of International Affairs 2(13):51-70.

Lewy, Guenter. 2000. The Nazi persecution of the gypsies. Oxford: Oxford University Press.

Matras, Yaron. 2000. Romani migrations in the post-communist era: their historical and political significance. Cambridge Review of International Affairs 12(2):32-50.

Okely, Judith. 1992. The traveller-gypsies. Cambridge: Cambridge University Press. Erstausgabe 1983.

Pavelčíková, Nina. 2004. Romové v českých zemích v letech 1945-1989 [Roma in Czech lands in 1945-1989]. Praha: Úřad dokumentace a vyšetřování zločinů komunismu.

Plavjanikova, Lucie, and Michal Ruzicka. 2008. Socio-prostorová dynamika prríbuzenství v cigánské osadě [socio-spatial dynamics of kinship in a gypsy settlement]. In Cikánské skupiny a jejich sociální organizace [gypsy groups and their social organization], eds. Marek Jakoubek, and Lenka Budilová, 305-325. Brno: CDK.

Prónai, Csaba. 2004. Gypsy migration in Hungary. In Roma migration in Europe: case studies, eds. Will Guy, Zdenek Uherek, and Renata Weinerova, 119-133. Münster: LIT.

Ringold, Dena. 2000. Roma and the transition in central and Eastern Europe: trends and challenges. Washington, D.C.: The World Bank. 
Ruzicka, Michal. 2006. Geografie socialni exkluze [geography of social exclusion]. Sociální studia 2:117-132.

Ruzicka, Michal. 2009. Researching and politicizing migration: the case of Roma/gypsies in postsocialist Czecho-Slovakia. In Boundaries in motion: rethinking contemporary migration events, eds. Radka Klvaňová, Ondřej Hofírek, and Michal Nekorjak, 70-103. Brno: CDK.

Ruzicka, Michal. 2011. Časoprostorové a infrastrukturní aspekty procesu sociální exkluze [Space-time and infrastructural aspects of social exclusion]. Czech Sociological Review 47(2):273-295.

Ruzicka, Michal. 2012. Continuity or rupture? Roma/gypsy communities in rural and urban environments under post-socialism. Journal of Rural Studies 28(2):81-88.

Scott, James. 1985. Weapons of the weak: everyday forms of peasant resistance. New Haven: Yale University Press.

Scott, James. 1998. Seeing like a state: how certain schemes to improve the human condition have failed. New Haven: Yale University Press.

Scott, James. 2009. The art of not being governed: an anarchist history of upland southeast Asia. New Haven: Yale University Press.

Sibley, David. 1981. Outsiders in urban society. Oxford: Blackwell.

Sibley, David. 1995. Geographies of exclusion: society and difference in the west. London: Routledge.

Silverman, Carol. 1982. Everyday drama: impression management of urban gypsies. Urban Anthropology 11:377-398.

Silverman, Carol. 1988. Negotiating 'gypsiness': strategy in context. The Journal of American Folklore 101(401):261-275.

Stewart, Michael. 1997. The time of the gypsies. Oxford: Westview Press.

Sutherland, Anne. 1975. The American Rom: a case of economic adaptation. In Gypsies, tinkers and other travellers, ed. Farnham Rehfish, 1-39. London: Academic Press.

Sway, Marlene. 1984. Economic adaptability: the case of the gypsies. Journal of Contemporary Ethnography 1(13):83-98.

Uherek, Zdeněk. 2004. The Czech republic and Roma migration after 1989. In Roma migration in Europe: case studies, eds. Will Guy, Zdenek Uherek, and Renata Weinerova, 71-100. Münster: LIT.

Vašečka, I., and M. Vašečka. 2003. Recent Romani migration from Slovakia to EU member states: Romani reaction to discrimination or Romani Ethno-tourism? Nationalities Papers 1(31):27-45.

Wacquant, Loïc. 2010. Crafting the neoliberal state: workfare, prisonfare, and social insecurity. Sociological Forum 25(2):197-220.

Weinerová, Renata. 2004. Slovakia and Roma migration after 1989. In Roma migration in Europe: case studies, eds. Will Guy, Zdenek Uherek, and Renata Weinerova, 101-118. Münster: LIT.

Wengle, John. 1988. Ethnographers in the field: the psychology of research. Tuscaloosa: University of Alabama Press.

Williams, Patrick. 1982. The invisibility of the Kalderash of Paris: some aspects of the economic activity and settlement patterns of the Kalderash Rom of the Paris suburbs. Urban Anthropology 11(3/4):315-346.

Young, Jock. 1999. The exclusive society: social exclusion, crime and difference in late modernity. London: SAGE.

Michal Ruzicka studied in Czech Republic (University of West Bohemia in Pilsen), Great Britain (University of Durham), United States (University of California at Berkeley) and in Austria (Universität Wien). In his own research, he has been studying the intersection between the mechanisms of social exclusion and ways how the excluded individuals and families respond to their disadvantaged status in the dominant society. Besides conducting long term ethnographic fieldwork in Roma/Gypsy settlements in Eastern Slovakia and in relegated neighborhoods in Czech cities, Michal Ruzicka has been studying the theories and practices of social classification, social exclusion, urban life, and the production of otherness and deviance. Besides contributing to numerous academic monographs, his articles have appeared in Czech Sociological Review and in Journal of Rural Studies. 